\title{
OBITUARIES
}

\section{Dr. D. D. Pratt, C.B.E.}

ALI, who at different stages of his scientific career knew Dr. D. D. Pratt will learn with regret of his death on May 5. As recently as 1959 he retired from the post of director of the National Chernical Laboratory after 34 years spent in the scientific service of the State.

David Doig Pratt, born at Anstruther in Fife in 1894, was educated at Waid Academy and the University of St. Andrews, which he entered in 1912. However, he joined the Army when war broke out in 1914, received a commission and served with the Highland Light Infantry. Wounded on the Somme, ho was mentioned in dispatches and promoted to captain. After the First World War he returned to St. Andrews, graduated M.A., B.Sc. with honours in chemistry in 1921 and was awarded a Carnegie Scholarship. This enabled him to start research under Prof. (now Sir Robert) Robinson. He took his Ph.D., became a Carnegie Fellow and continued his work at the University of Manchester, still in association with Prof. Robinson. Pratt was one of the first of many in Robinson's school who found the naturally occurring flower pigments a rewarding study.

In 1925 Dr. Pratt made the move which was to determine the course of his future career. The Department of Scientific and Industrial Research was on the point of setting up at Teddington in a very small way a laboratory to be known as the Chemical Research Laboratory. The sponsors of this scheme were Sir Richard Threlfall and H. T. (later Sir Henry) Tizard; Prof. G. T. (later Sir Gilbert) Morgan was persuaded to take charge of what was avowedly an experiment. Pratt accepted a post in the unit when its staff numbered less than a dozen and was Morgan's stoutest supporter in the task of building the prestige of the laboratory and establishing its role as a national institution. In 1958 the embryo of 1925 officially became the National Chemical Laboratory with a staff of more than 200. Pratt had been its director for some seven years, and as officer-incharge or superintendent he had been its effective head at other difficult periods during and after the Second World War when the post of director had been vacant.

The project which Morgan assigned to Pratt was an investigation of coal tars and liquors, very different in character from the synthetic organic chemistry in which he had made his mark, but equally one which gave scope to his ability as a chemist. Backed by Morgan and aided by a small group which he inspired with his own enthusiasm, Pratt set about nothing less than the complete revivification of coal tar research in Britain. Attention was first directed to tars from the low-temperature carbonization of coal. This method of making smokeless solid fuel was then undergoing development, and it was clear that no process could succeed unless the by-product tars could find profitable application. The $\mathrm{s}$ tension of precise knowledge in regard to the constitution of these new materials must proceed pari passu with utilitarian aims. Aware of the very reactive nature of these tars, Pratt systematized the use of extraction by solvents and vacuum distillation in their rational analysis. But this was no more than a beginning.

The Teddington work, new in pattern, caught the attention of influential leaders in the industry and created a new climate of opinion as to what might be achieved by research well directed. When in 1934 the Association of Tar Distillers gave financial support to the Laboratory for work on one of the industry's most troublesome problems--the disastrously rapid corrosion of tar stills caused by certain types of tar-it had taken the first step on what turned out to be a long road. The industry formed its own Research Association in 1948, and in 1950 the ministerial head of the Department of Scientific and Industrial Research (Sir John Anderson), in the presence of its secretary (Sir Ben Lockspeiser), gave the blessing of the Department to the newly established Coal Tar Research Station at Gomersal. Pratt witnessed with amused satisfaction the lighting of a symbolical Bunsen burner by Sir John, although for him the ceremony was valedictory rather than inaugural.

After 1938 Pratt was fully engaged in the administration of the Laboratory's total research effort. His concern now was to maintain an environment in which good scientific work could be done by his colleagues.

One quality which fitted him for the responsibilities he hold so long Pratt possessed in full measure. $\mathrm{He}$ had an understanding of human nature and was on easy terms with all members of his staff regardless of status or rank. He was shrewd in judging issues in which policy and personalities were mixed with matters purely scientific.

Dr. Pratt shared most of the simple pleasures of the ordinary man. He had an interest in every form of sport; he particularly liked to be among the crowd at a football match. He grew flowers in his garden; regularly sought relaxation at a variety theatre or cinema; and he could always be persuaded to attend. a staff social and play cards, billiards or snooker, or join in a dance.

The effort to make the Laboratory the national institution he thought it should become was steadily pursued, and the distinctions bestowed on Dr. Pratt, C.B.E. and an honorary LL.D. of the University of St. Andrews, were recognition of the merit of his service to the Department and his success in securing for the Laboratory the esteem of the scientific world.

F. A. Corlson

\section{Dr. G. I. Patel}

Dr. Govindbhai Ishwerbhat Patel, who died on March 10, was born at Savli, District Baroda of the Gujarat State, on June 21, 1921. He was the second son of the late Ishwerbhai Kesurbhai Patel, an industrious farmer, having 5,000 acres of land under cultivation, who took great interest in the proper education of his sons. Young Govinddas, as he was addressed by his kinsmen, was different from the rest of his brothers and cousins, studying at Baroda. During his school days at Baroda, he showed average progress, but his zeal for knowledge 
was such that nothing was allowed to come in its way. Leaving aside the hardships of accommodation, food, etc., the main difficulty was the choice of his career. He matriculated in 1939 and joined Baroda College. The new atmosphere had a profound influence on him; the once meek and average student now began to shine as a scholar in the truest sense of the term.

His patriotism and eagerness for the uplift of the rural masses attracted him to the study of agriculture. He then went to the then only college of agriculture, claimed to be the best in South-east Asia, namely, that at Poona. Here his progress was remarkable and he secured first class with distinction in the B.Sc.(Agric.) examination in the University of Bombay in 1946 .

While studying he decided to go to the United States in order to study agriculture at an advanced level. There he ontered the Graduate School of the Iowa State College and the University of California at Davis. As he was much interested in horticulture, he preferred the University of California and receiver his M.S. degree in horticulture in 1948 and Ph.D. degree in plant genetics in 1951 working under Prof. H. P. Olmo on the genetics and cytogenetics of the grape vine. During his stay there he compoted in two examinations and was awarded two fellowships of several thousand rupees in order to continue his studies. He returned to India in 1951 .

$\mathrm{He}$ accepted a Class III post in a Government Vegetable Seed Multiplication Farm in the Kulu Valley. After serving there for a year he left and joined the Agricultural Research Institute, Sabour, Bhagalpore, in an honorary capacity to work under Dr. R. H. Richharia, the geneticist and plant breeder and director of the Institute, and he published some important papers. Later, he was appointed cytogeneticist in March 1953 by the Indian Central Jute Committee at its Jute Agricultural Research Institute, Barrackpore. From there he published several important papers on the cytogenetics of jute in several journals, which attracted world-wide attention. His papers on the grape vine were also outstanding. Later in $\mathbf{1 9 5 6}$ he was appointed areca-nut specialist at Vittal. He worked there for some time and published a few papers. As the post carried more administration, he left and returned to his native home at Baroda and entered business for two years. Afterwards, he took up horticultural researches on joining the Scientists' Pool organized by the Council for Scientific and Industrial Research, and he was posted to the National Botanic Gardens, Lucknow. To continue his work it was necessary to go to the Banthra Farm, a few miles from Lucknow. On March 9, while cycling to the farm, he met with a fatal accident by colliding with a speeding car. Although he received prompt and adequate medical help, he succumbed to his injuries on March 10.

R. M. Datra

\section{Mr. J. K. Starnecki}

Mr. Jerzy Kazimerz Starnecki, who died on May 15, was born in Poland on August 26, 1908. $\mathrm{He}$ gained a diploma in engineering at the University of Warsaw and in 1935 was appointed head of the Inspection Branch of the Polish National Armament Factories, Radom. After the outbreak of hostilities in 1939 ho served with distinction the Polish Armed Forces in France. In 1941 he was chosen for a special assignment as design engineer with the Research and Development Department of the Polish Army in the United Kingdom.

After the War, Mr. Starnecki spent a short time as a research engineer at Signals Research and Development Establishment; then, in 1947, he joined Pye, Ltd., where, among other projects, he played a leading part in the design of a new optical system used in the gunsight of the Conqueror tank and in the servo-controlled automatic stabilizing gear. After a successful stay of seven years with Pye, Ltd., Mr. Starnecki was appointed chief engineer and head of development of W. G. Pye and Co., Ltd., where he remained until his death. There his great foresight and sound engineering knowledge influenced the design of nearly all instruments. He was an active associate member of the Institution of Mechanical Engineers. He made a constant endeavour to keep abreast of latest scientific developments and several patents are to his credit. $\mathrm{He}$ has served on the council of the British Scientific Instrument Research Association and was a committee member of the Scientific Instrument Manufacturers' Association of Great Britain, Ltd.

Mr. Starnecki was a rather quiet little man but with a good sense of humour and a smile for every. body. In his limited amount of spare time he was a keen gardener. His sudden and untimely death came as a great shock. He will be missed by all who worked with him and remembered not only as an outstanding engineer but also for the great range of his human sympathies.

\section{NEWS and VIEWS}

\section{International Meteorological Organization Prize for 1962 : Dr. A. Angström}

Dr. Anders Axaström from Bromma, Sweden, has been awarded the International Meteorological Organization Prize for outstanding work in meteorology and international collaboration. Dr. A. Angström studied at the Universities of Uppsala, New York and Jena. He obtained the degrees of Master of Science and 'Filosofie Doktor' and in 1916 became assistant professor of meteorology in Uppsala. After participating in several scientific expeditions and work at Cornell University as a Fellow in physics, Dr. Angström became State Meteorologist and later First State Meteorologist at the Swedish Meteor. ological and Hydrological Institute in 1919. In 1940 he was appointed assistant director and chief of the Meteorological Bureau and in 1949 director of the Institute. He retired from this post in 1954. Dr. Angström is a member of the Royal Swedish Academy of Science and of the Royal Swedish Academy of Forestry and Agriculture. His contribution to international collaboration has mainly been in meteorology, particularly in the field of solar and atmospheric radiation. He has participated in various meetings of the International Meteorological Organ. ization and the World Meteorological Organization as well as of the International Union of Geodesy and Geophysics. The International Meteorological Organization Prize, which consists of a gold medal, was 